\title{
14. The Impact of Coastal FDI on Inland Economic Growth in China
}

Chunlai Chen

\section{Introduction}

One of the most successful aspects of China's economic reform and open-door policy implemented since late 1978 has been attracting inflows of foreign direct investment (FDI). By the end of 2014, China had attracted US\$1.5 trillion in FDI inflows, making it the largest FDI recipient in the developing world. Coastal and inland regions vary in their attractiveness as locations for FDI, and Chinese policies have favoured coastal regions through the establishment of special economic zones (SEZs) and various preferential treatments (Chen 2011). FDI inflows have therefore been concentrated in the coastal regions, which account for about 80 per cent of total FDI inflows into China.

That spatial concentration of FDI within China could have consequences for inland regions. On the one hand, it could be drawing factors of production away from inland regions and providing competition in product markets, both domestic and international. This would produce unbalanced regional growth and widen income inequality between coastal and inland regions. On the other hand, inland regions less well-served by FDI could benefit from coastal FDI if there are inter-regional knowledge spillovers from coastal to inland regions.

This chapter aims to investigate whether the dense concentration of FDI in China's coastal regions has boosted or undermined the economic growth of inland regions. Specifically, the study uses Chinese province-level data to test whether there are inter-regional knowledge spillovers from FDI concentrated in coastal regions and also how these spillovers are affected by FDI directed to different trade activities - processing trade ${ }^{1}$ versus ordinary trade. This study

1 There are two kinds of processing trade: processing or assembling with imported materials; and processing or assembling with supplied materials. For the first, the processing firms import - free of customs duty - materials and components that are used to produce finished goods and export them to international markets. In the case of the second, the processing firms process or assemble duty-free materials and components supplied by foreign firms and export finished products. They are paid a fee for the processing or assembling activities. The foreign firms control both the supply of the materials and the entire international marketing of the processed or assembled products. 
makes two contributions to the literature. First, it tests directly inter-regional knowledge spillovers from FDI - specifically, spillovers from coastal FDI to inland provinces. This serves to add new empirical evidence to the sparse literature on inter-regional knowledge spillovers of FDI. Second, the study tests how FDI in different types of trade activities — processing versus ordinary trade - in coastal regions affect the economic growth of inland provinces. This could shed light on the effectiveness of processing trade policies implemented in coastal regions since the mid-1980s.

The study finds that, on average, coastal FDI has had a negative impact on economic growth in inland provinces. By further dividing coastal FDI into northern and eastern FDI and southern FDI, based on the depth of engagement in processing trade, the study finds that FDI in the northern and eastern coastal provinces (which are moderately engaged in processing trade) has positive spillovers on the economic growth of inland provinces, while FDI in southern coastal provinces (those heavily engaged in processing trade) has had a negative effect on the economic growth of inland provinces. It is also interesting to note that FDI in other inland provinces that are less engaged in processing trade is found to have positive spillovers on the economic growth of inland provinces. One explanation for this could be that ordinary trade generates larger industrial linkages with inland regions than does processing trade, as the latter is based largely on processing imported inputs.

The rest of this chapter is structured as follows: the second section discusses the theoretical explanations of how knowledge spillovers from FDI contribute to developing host countries' economic growth and presents a brief literature review. Section three sets out the theoretical framework of this analysis and specifies the empirical model; section four describes the data and specifies the variables; section five presents the results of the regression analysis and explains the estimation results. Section six provides the conclusion and policy implications.

\section{Literature review}

FDI is one of the most important means through which international knowledge spillovers take place. Because of ownership advantages and the possession of firm-specific intangible assets, FDI can generate knowledge spillovers to domestic firms (Caves 1996; Dunning 1993). FDI knowledge spillovers are regarded as an important source of knowledge in developing countries. Demonstration effects, human resource movement, vertical industrial linkages, technical assistance 
and information flows are examples of knowledge spillovers via which FDI can improve the productivity and competitiveness of local firms, and thus promote economic growth in the host country.

FDI knowledge spillovers can be horizontal or vertical. Horizontal spillovers take place within the same industry through demonstration effects and labour turnover. FDI can, however, also impose competition on domestic firms, crowding them out of product markets and competing with them in labour and resource markets (for example, Aitken and Harrison 1999; Chen 2011; Chen et al. 2013; Fu 2011; Hu and Jefferson 2002; Hu et al. 2005).

Vertical FDI knowledge spillovers arise through forward and backward industrial linkages between FDI firms and domestic firms within the supply chain (for example, Chen et al. 2013; Girma et al. 2004; Javorcik 2004; Kneller and Pisu 2007). When FDI firms provide higher-value intermediate materials for their customers or when they transfer product knowledge to their suppliers, they contribute to domestic firms' productivity and competitiveness in upstream and downstream industries, in turn increasing local economic growth.

Do FDI knowledge spillovers also take place between regions within a country? Theoretically, inter-regional knowledge spillovers of FDI could take place via at least four channels. The first is inter-regional movement of labour: FDI stimulates inter-regional labour migration, and when employees trained by FDI firms move back to their own regions, they can bring knowledge to local firms and thus knowledge diffusion takes place (Fosfuri et al. 2001; Holger and Strobl 2005). ${ }^{2}$ Second are inter-regional backward and forward industrial linkages: FDI firms may develop inter-industry linkages with local firms in other regions, providing those firms with greater opportunities in economies of scale and productivity improvement (Chen et al. 2013; Javorcik 2004; Kugler 2006; Liu 2008). Third, the innovations and research and development (R\&D) activities of FDI firms might generate inter-regional knowledge spillovers through imitation and reverse engineering by firms in other regions (Bronzini and Piselli 2009; Funke and Niebuhr 2005; Keller 2002; Kuo and Yang 2008). The fourth channel is formed by the macroeconomic consequences of increased demand for products from other regions as a result of the increased income generated by FDI (Brun et al. 2002; Zhang and Felmingham 2002). FDI could, however, also impose competition on other regions - for example, crowding them out of product

2 Cai and Wang (2003) show that in 2000 there were 124.6 million internal migrants in China, of whom 73.4 per cent were inter-provincial migrants. The eastern provinces are the main destination for interregional migrants. More than 60 per cent of immigrants in eastern provinces were from inland regions. Bao et al. (2007) find that when real FDI rose by 1 per cent, internal migration rose by more than 1.25 per cent during the 1990s. The workers returning from the coastal foreign firms accelerated the inland regions' processes of imitation of advanced technologies brought by coastal foreign firms (Du et al. 2005; Rozelle et al. 1999). 
markets and competing with them in labour and resource markets (Aitken and Harrison 1999; Branstetter and Feenstra 2002; Fu 2011; Hu and Jefferson 2002; $\mathrm{Hu}$ et al. 2005).

The literature on knowledge spillovers from FDI is extensive and growing. Studies on the inter-regional knowledge spillovers of FDI, however, remain few. Girma and Wakelin (2007) find that while domestic firms in the United Kingdom benefit positively from foreign firms in the same region and that FDI spillovers do occur within regions, they find no relationship (even a negative relationship) between productivity in one region and FDI in other regions. Halpern and Murakozy (2007) examine firm-level data for Hungary and find that the effect of regional and county boundaries is insignificant.

In the case of China, a few studies have used firm-level data to test regional spillovers from FDI, but reached inconsistent conclusions. Girma and Gong (2008) use data for state-owned enterprises (SOEs) from 1999 to 2002 and find that the activities of foreign firms do not benefit SOEs in other regions. Liu et al. (2009) find backward and forward FDI spillovers among firms at the regional level only. $\mathrm{Xu}$ and Sheng (2012) use firm-level census data from the manufacturing industry for 2000-03 and find that domestic firms benefit more from the presence of foreign firms in the same sector within the same region than either between sectors or between regions.

However, a few studies find positive inter-regional spillovers from FDI. Madariaga and Poncet (2007) use city-level data for 1990-2002 and find that FDI inflows affect economic growth in surrounding cities. Ouyang and Fu (2012) use city-level data for 1996-2004 and find that FDI in coastal regions has positive inter-regional spillovers on the economic growth of inland regions. In contrast, using provincial industry-level data for the period 1990-2005, Wang et al. (2013) find that inter-regional FDI spillovers are consistently negative - that is, foreign investment in one region attracts resources away from regions with less FDI, and thus has a negative influence on the growth of industrial output in neighbouring regions. Additional study of the impact of FDI on inter-regional knowledge spillovers is evidently required in order to better understand its role in the economic growth of host countries.

This study adds to the existing literature by examining inter-regional knowledge spillovers from FDI in China - the largest developing country and also the largest FDI recipient among the developing economies. This study specifically investigates and answers two questions: 1) are there inter-regional knowledge spillovers from coastal FDI on the economic growth of inland regions; and 2) do different types of FDI in coastal regions have different impacts on the economic growth of inland provinces? 


\section{The model}

We use the following aggregate production function to estimate the impact of coastal FDI on the economic growth of inland provinces (Equation 14.1).

\section{Equation 14.1}

$Y_{i t}=A_{i t} L_{i t}^{\beta_{1}} D K_{i t}^{\beta_{2}} F K_{i t}^{\beta_{3}}$

In Equation 14.1, $Y_{i t}$ is the real gross domestic product (GDP) of inland province $i$ in year $t ; A_{i t}$ is the total factor productivity (TFP) level of inland province $i$ in year $t ; L_{i t}$ is total labour input of inland province $i$ in year $t ; D K_{i t}$ is domestic capital stock of inland province $i$ in year $t$; and $F K_{i t}$ is the foreign capital stock of inland province $i$ in year $t$.

Under these assumptions, within the aggregate production function, FDI is treated as a separate factor of capital input $(F K)$ alongside domestic capital input $(D K)$ and labour input $(L)$.

Theoretically, because FDI brings into the host country a package of capital, technology, production knowhow, management skills, marketing skills and information, competition, and so on (Caves 1996; Dunning 1993), it is expected that FDI can increase the host country's economic growth by a number of means.

First, FDI inflows will increase demand for labour and create employment in a host country, especially a developing country. The increase in employment will contribute to an increase in total output, thus leading to a higher output level along the existing production function. It is expected that the higher the level of employment created by FDI, the higher will be the output growth of the host economy.

Second, FDI inflows increase the host country's fixed capital formation. FDI is believed to be a leading source of technology transfer and human capital augmentation in developing countries. Technological progress takes place through a process of capital deepening through the introduction of new varieties of knowledge-based capital goods. It also proceeds via specific productivity-increasing labour training and skill acquisition promoted by multinational enterprises (MNEs). Therefore, through capital augmentation in the recipient economy, FDI is expected to be growth enhancing by encouraging the incorporation of new inputs and technologies into the production function, thus shifting the production function of the host country. This positive shifting effect is the contribution to output growth of FDI as a capital input. It is expected that the higher the foreign capital input, the higher will be the output growth of the host economy. 
Third, through knowledge spillovers such as learning by doing or learning by watching (demonstration effects), R\&D, human resource movement, training courses, vertical industrial linkages, technical assistance and exposure to fierce competition, FDI is expected to increase the productivity and efficiency of local firms in the host country. As a result, FDI can shift the production function of the host economy to a higher level. It is expected that the greater the presence of FDI, the higher will be the spillover effects of FDI on local economic growth.

Fourth, FDI can generate inter-regional knowledge spillovers to increase the productivity and efficiency of firms in other regions through the interregional movement of labour, inter-regional backward and forward industrial linkages, inter-regional imitation and reverse engineering, and inter-regional macroeconomic consequences, such as increased market demand for products from other regions as a result of increasing incomes generated by FDI. As a result of inter-regional knowledge spillovers, FDI in one region can shift the production function of another region to a higher level. It is expected that the higher the regional FDI stock to which a region is exposed, the higher the interregional knowledge spillovers of FDI on that region's economic growth will be. However, FDI in one region may also impose competition on other regions, crowding them out of the product market and competing with them in the labour and resource markets. So, the net effect of inter-regional spillovers from FDI in one region on the economic growth of other regions is inconclusive, subject to empirical investigation. In this study, to investigate the inter-regional knowledge spillovers of FDI on inland provinces, we define two kinds of interregional FDI knowledge spillovers. One is the inter-regional knowledge spillover of FDI from coastal regions on an inland province, and the other is the interregional knowledge spillover of FDI on an inland province from other inland provinces.

Given our assumptions of the model of the spillover channels of FDI, TFP, $A_{i t^{\prime}}$ can be defined as in Equation 14.2.

\section{Equation 14.2}

$$
A_{i t}=B_{i t} C R F K_{i t-1}^{\alpha_{1}} O I R F K_{i t-1}^{\alpha_{2}} e^{g\left(S F K_{i t-1}, t, H K\right)}
$$

In Equation 14.2, $A_{i t}$ is the TFP level of inland province $i$ in year $t ; B_{i t}$ is the residual TFP level of inland province $i$ in year $t ; S F K_{i t-1}$ is the presence of FDI in inland province $i$ in year $t-1$, which captures the spillovers from FDI within inland province $i$; $C R F K_{i t-1}$ is coastal region FDI stock exposed by inland province $i$ in year $t-1$, which captures the inter-regional spillovers of coastal province FDI on inland province $i$; OIRFK $K_{i t-1}$ is other inland region FDI stock exposed by inland province $i$ in year $t-1$, which captures the inter-regional spillovers of FDI from other inland provinces on inland province $i ; t$ is a time trend, which 
captures the Hicks-neutral technological progress in inland province $i$; and $H K$ is human capital in inland province $i$ in year $t$, which is expected to have a positive impact on economic growth.

Incorporating Equation 14.2 into the aggregate production function Equation 14.1 , and rearranging the items on the right-hand side, with the addition of a constant term $\left(\beta_{0}\right)$ and an error term $\left(\varepsilon_{\mathrm{it}}\right)$, we obtain the following empirical regression (Equation 14.3).

\section{Equation 14.3}

$L n Y_{i t}=\beta_{o}+\beta_{1} L n L_{i t}+\beta_{2} L n D K_{i t}+\beta_{3} L n F K_{i t}+\beta_{4} S F K_{i t-1}+\beta_{5} L n C R F K_{i t-1}+$ $\beta_{6} \operatorname{LnOIRFK}_{i t-1}+\beta_{7} H K_{i t}+\beta_{8} t+\varepsilon_{i t}$

In Equation 14.3, $i(i=1,2, \ldots, 20)$ and $t(t=1987, \ldots, 2010)$ denote inland province $i$ and year $t ; Y$ is real provincial GDP; $L$ and $D K$ are labour and domestic capital stock; ${ }^{3} F K$ is foreign capital stock, which serves to capture the contribution of FDI to economic growth through capital augmentation; SFK is the presence of FDI in an inland province (share of foreign capital stock in total capital stock), which captures the spillover effects of FDI within an inland province; $C R F K$ is the coastal region foreign capital stock to which an inland province is exposed, which captures the inter-regional spillovers of coastal FDI; OIRFK is other inland foreign capital stock to which an inland province is exposed, which captures the inter-regional spillovers of other inland FDI; $H K$ is human capital; and $t$ is a time trend, which captures the Hicks-neutral technological progress.

This specification allows not only testing of the direct contribution of FDI to provincial economic growth (if coefficient $\beta_{3}$ is positive and statistically significant then it can be ascertained that FDI has directly contributed to inland province economic growth through capital input), but also further tests undertaken on the spillover effects of FDI on inland province economic growth in three aspects. First, we can test the spillover effects of FDI on economic growth within an inland province. If the coefficient $\beta_{4}$ is positive and statistically significant, there is evidence that FDI has generated positive spillover effects within an inland province. Second, we can test the inter-regional spillover effects of FDI from coastal provinces on inland province economic growth. If the coefficient $\beta_{5}$ is positive and statistically significant, there is evidence that FDI in coastal provinces has generated positive inter-regional spillovers on the economic growth of inland provinces. Third, we can test the inter-regional spillover effects of FDI from other inland provinces on the economic growth of

3 Official data of labour employed by FDI at the provincial level are not available, so the total numbers for labour in each province are used in the regression. 
an inland province. If the coefficient $\beta_{6}$ is positive and statistically significant, there is evidence that FDI in other inland provinces has generated positive interregional spillover effects on an inland province's economic growth.

Equation 14.3 is an augmented production function that we use to estimate the intra-provincial and inter-regional spillover effects of FDI on China's inland provinces' economic growth. The first part of the analysis is to investigate whether there are inter-regional spillover effects on inland provinces from FDI in coastal provinces. The second part of the analysis is to investigate whether FDI in different trade activities generates different inter-regional spillover effects on inland provinces' economic growth by dividing coastal FDI into northern and eastern coastal FDI and southern coastal FDI based on the level of engagement in processing trade. The following section outlines the data and specifies the variables.

\section{Data and variable specification}

This study uses province-level data covering China's 31 provinces and the period 1987-2010. The 31 provinces are divided into 11 coastal provinces ${ }^{4}$ and 20 inland provinces. ${ }^{5}$ The data for provincial GDP $(Y)$ and provincial total capital stock (billion RMB at 1978 prices) are from Wu (2009). ${ }^{6} \mathrm{Wu}$ uses the conventional perpetual inventory method by employing the recently released national accounts figures to derive a capital stock series for China's 31 provinces and three economic sectors (that is, agriculture, manufacturing and services) for the period 1977-2010. This produces one of the most comprehensive datasets of capital stock series for China's 31 provinces and three economic sectors.

\section{Calculating foreign capital stock}

The data for FDI stock $(F K)$ are calculated in several steps. First, the US dollar value of annual FDI inflows is converted into a renminbi (RMB) value by using the annual average official exchange rate. Second, the RMB value of annual FDI inflows is deflated into the real value at 1978 prices by using China's national consumer price index (CPI). Third, a 5 per cent depreciation rate is assumed for foreign capital (FDI). Finally, FDI stock is accumulated for each year end measured in billion RMB at 1978 prices.

4 The 11 coastal provinces are Beijing, Fujian, Guangdong, Hainan, Hebei, Jiangsu, Liaoning, Shandong, Shanghai, Tianjin and Zhejiang.

5 The 20 inland provinces are: Anhui, Chongqing, Gansu, Guizhou, Guangxi, Heilongjiang, Henan, Hubei, Hunan, Inner Mongolia, Jiangxi, Jilin, Ningxia, Qinghai, Shaanxi, Shanxi, Sichuan, Tibet, Xinjiang and Yunnan.

6 Data for 2007-10 are provided by Wu (2009). 


\section{Calculating the share of foreign capital}

The presence of FDI in an inland province is measured as the share of FDI stock in the total capital stock of an inland province (SFK) to capture the intra-province spillover effects of FDI on provincial economic growth. The share of FDI stock is calculated as FDI stock over total capital stock of an inland province. It is reasonable to assume that FDI inflows and spillover effects have a time lag, so the value of one year lag of $S F K$ is used in the model. The use of the lagged value of $S F K$ also can reduce the potential problem of endogeneity in the regression. The hypothesis is that provinces with a higher share of FDI stock in total capital stock will have higher spillover effects from FDI to the local economy, thus increasing the productivity and efficiency of local firms and promoting provincial economic growth.

\section{Measuring coastal region FDI}

We use the formula $\Sigma_{j t} F D I_{j t} \times e^{-D i j}$ to measure the coastal region FDI stock ( $\left.C R F K\right)$ to which an inland province is exposed, ${ }^{7}$ where $F D I_{j t}$ is the amount of FDI stock in coastal province $j$ in year $t ; D_{i j}$ is the distance in $1,000 \mathrm{~km}$ between inland province $i$ and coastal province $j$; and $e^{-D i j}$ works as a discount factor, since greater distance implies higher transaction and transportation costs, which make interregional migration and access to coastal markets more difficult. Therefore, $F D I_{j t}$ $\times e^{-D i j}$ measures the amount of FDI stock in coastal province $j$ that might affect inland province $i$, and $\sum_{j t} F D I_{j t} \times e^{-D i j}$ is the total amount of FDI stock from all coastal provinces that might affect inland province $i$ in year $t$.

Different coastal regions attract different types of FDI. FDI in southern coastal provinces is mainly directed towards processing trade, while FDI in northern and eastern coastal provinces is moderately engaged in processing trade (Chen 2011). In addition to estimating the average inter-regional spillovers, we also estimate inter-regional spillovers of FDI from different coastal regions. We use the same formula as above to calculate the amount of FDI stock in the northern and eastern coastal provinces $(N \& E C R F K)^{8}$ and the amount of FDI stock in the southern coastal provinces $(S C R F K)^{9}$ to which an inland province is exposed. Using the same reasoning as for the share of foreign capital, the value of one year lag is used for all coastal region FDI stock variables in the model.

7 Keller (2002) uses a similar method to measure the effective foreign-country R\&D to which a country is exposed.

8 The northern and eastern coastal provinces are Beijing, Hebei, Jiangsu, Liaoning, Shandong, Shanghai, Tianjin and Zhejiang.

9 The southern coastal provinces are Fujian, Guangdong and Hainan. 


\section{Controlling for FDI in other inland provinces}

FDI in other inland provinces may also generate inter-regional spillovers and influence the economic growth of the inland province. To control for the potential inter-regional spillovers from other inland provinces on an inland province's economic growth, we use the same formula to calculate the FDI stock of other inland provinces $(O I R F K)$ to which an inland province is exposed. As above, the value of one year lag is used for the other inland region FDI stock variable $(O I R F K)$ in the model.

\section{Measuring other inland province variables}

The domestic capital stock $(D K)$ of each inland province is obtained by deducting the FDI stock $(F K)$ from the total capital stock. Labour $(L)$ is the total number of people employed in each province measured as million persons. Human capital $(H K)$ is measured as the ratio of the number of university students to the total population of each inland province.

The dependent and independent variables and the data sources are summarised in Table 14.1.

Table 14.1 Variables of the impact of FDI on the economic growth of China's inland provinces

\begin{tabular}{|c|c|c|}
\hline Variable name & Specification of variables & Sources \\
\hline \multicolumn{3}{|c|}{ Dependent variable } \\
\hline$Y_{i t}$ & $\begin{array}{l}\text { GDP of inland province } i \text { in year } t \text {. RMB billion at } \\
1978 \text { prices }\end{array}$ & $\begin{array}{l}\text { Wu (2009) and NBS (various } \\
\text { issues) }\end{array}$ \\
\hline \multicolumn{3}{|c|}{ Independent variables } \\
\hline$L_{i t}$ & $\begin{array}{l}\text { Total number of employed people of inland } \\
\text { province } i \text { in year } t \text {. Million persons }\end{array}$ & NBS (various issues) \\
\hline$D K_{i t}$ & $\begin{array}{l}\text { Domestic capital stock of inland province } i \text { in year } \\
t \text {. RMB billion at } 1978 \text { prices }\end{array}$ & $\begin{array}{l}\text { Calculated from Wu (2009) and } \\
\text { NBS (various issues) }\end{array}$ \\
\hline$F K_{i t}$ & $\begin{array}{l}\text { FDI stock of inland province } i \text { in year } t \text {. RMB } \\
\text { billion at } 1978 \text { prices }\end{array}$ & $\begin{array}{l}\text { Calculated from, for before and } \\
\text { including } 2005, \text { NBS (various } \\
\text { issues); after 2005, PBS (various } \\
\text { issues of each province) }\end{array}$ \\
\hline$S F K_{i t-1}$ & $\begin{array}{l}\text { Share of FDI stock in total capital stock of inland } \\
\text { province } i \text { in year } t-1 \text {. Percentage }\end{array}$ & Same as above \\
\hline CRFK $_{i t-1}$ & $\begin{array}{l}\text { Coastal region FDI stock exposed by inland } \\
\text { province } i \text { in year } t-1 \text {. RMB billion at } 1978 \text { prices }\end{array}$ & Same as above \\
\hline OIRFK $_{i t-1}$ & $\begin{array}{l}\text { Other inland region FDI stock exposed by inland } \\
\text { province } i \text { in year } t-1 \text {. RMB billion at } 1978 \text { prices }\end{array}$ & Same as above \\
\hline
\end{tabular}




\begin{tabular}{|l|l|l|}
\hline Variable name & Specification of variables & Sources \\
\hline N\&ECRFK & $\begin{array}{l}\text { Northern and eastern coastal region FDI stock } \\
\text { exposed by inland province } i \text { in year } t-1 \text {. RMB } \\
\text { billion at 1978 prices }\end{array}$ & Same as above \\
\hline SCRFK $_{i t-1}$ & $\begin{array}{l}\text { Southern coastal region FDI stock exposed by } \\
\text { inland province } i \text { in year } t-1 \text {. RMB billion at 1978 } \\
\text { prices }\end{array}$ & Same as above \\
\hline$H K_{i t}$ & $\begin{array}{l}\text { Human capital of inland province } i \text { in year } t \\
\text { measured as the ratio of the number of university } \\
\text { students to total population. Percentage }\end{array}$ & NBS (various issues) \\
\hline
\end{tabular}

\section{Estimation Results}

\section{Estimates of average inter-regional spillover effects}

The data used in the regression are a panel dataset at the province level, containing China's 19 inland provinces for the period 1987-2010. ${ }^{10}$ We first conduct a Hausman test to choose between the random-effects model and the fixed-effects model for the regression. The Hausman test prefers the fixed-effects model. Therefore, we estimate Equation 14.3 under the fixed-effects model in order to eliminate the province-specific and time-invariant factors that could affect economic growth. The regression results are reported in Table 14.2.

The regression results show that domestic capital input $(D K)$ is positive and statistically significant at the 1 per cent level, while labour input $(L)$ is negative but insignificant. This implies that the marginal product of domestic capital is much higher than that of labour due to the relatively abundant labour supply and scarcity of capital in inland provinces. The variable of human capital $(H K)$ is positive and statistically significant at the 1 per cent level, which provides empirical evidence that human capital contributes to economic growth. The Hicks-neutral technological progress represented by the coefficient on a time trend $(t)$ is positive and statistically significant at the 1 per cent level, indicating that inland provinces experience technological progress and move onto a higher steady-state technology over time. 
Table 14.2 Estimating inter-regional spillovers of FDI on inland province economic growth, 1987-2010 (dependent variable: $\operatorname{LnY}$ )

\begin{tabular}{|c|c|}
\hline Independent variables & Fixed effects \\
\hline Constant & $\begin{array}{r}1.7583 \\
(9.13)^{\star \star \star \star}\end{array}$ \\
\hline$L n L$ & $\begin{array}{r}-0.0442 \\
(-0.83)\end{array}$ \\
\hline $\operatorname{LnDK}$ & $\begin{array}{r}0.4095 \\
(15.98)^{* * *}\end{array}$ \\
\hline LnFK & $\begin{array}{r}0.0615 \\
(9.09)^{* * *}\end{array}$ \\
\hline$H K$ & $\begin{array}{r}0.0570 \\
(3.44)^{* * *}\end{array}$ \\
\hline$t$ & $\begin{array}{r}0.0545 \\
(16.07)^{\star * *}\end{array}$ \\
\hline SFKt-1 & $\begin{array}{r}-0.0021 \\
(-0.43)\end{array}$ \\
\hline LnCRFKt-1 & $\begin{array}{l}-0.2103 \\
(-9.17)^{\star * *} \\
\end{array}$ \\
\hline LnOIRFKt-1 & $\begin{array}{l}0.1541 \\
(6.74)^{\star \star \star}\end{array}$ \\
\hline $\begin{array}{l}\text { No. of observations } \\
\text { No. of groups } \\
\mathrm{R}^{2} \\
\text { F-statistics }\end{array}$ & $\begin{array}{r}446 \\
19 \\
0.75 \\
9288^{* * *}\end{array}$ \\
\hline
\end{tabular}

* Statistically significant at 0.10 level.

** Statistically significant at 0.05 level.

*** Statistically significant at 0.01 level.

Note: t-statistics are in parentheses.

Source: Author's own estimations.

Turning to the variables of our main interest: first, the variable of foreign capital stock $(F K)$ is positive and statistically significant at the 1 per cent level, which provides strong support for the idea that FDI as a factor of capital input directly contributes to inland province economic growth. The estimation results imply that inland provinces with higher FDI inflows will have higher economic growth as a direct result of the increase in foreign capital input.

Second, the variable of the share of FDI stock in total capital stock $(S F K)$ the spillovers of an inland province's own FDI - is negative and insignificant. This finding is consistent with Chen $(2013,2014)$, who finds that FDI in China's inland provinces has not generated significant spillovers on the local economy due to the low level of FDI. Nunnenkamp and Stracke (2007) also find that FDI in poor regions in India is too small to generate spillover effects to boost local economic growth. 
Third, the variable of OIRFK - the FDI stock of other inland provinces - is positive and significant at the 1 per cent level, which implies that FDI in other inland provinces has generated positive spillovers on inland provinces. This may be because of technology spillovers through backward and forward industrial linkages, information flows and the movement of labour between FDI firms in inland provinces and local economies, thus increasing the economic growth of inland provinces.

Fourth, on the other hand, the variable of $C R F K$ - the FDI stock in coastal provinces - is negative and significant at the 1 per cent level, which implies that FDI in coastal provinces has had a negative impact on the economic growth of inland provinces. This might be explained by the following two points.

The first is competition between coastal FDI firms and inland provinces. Coastal FDI firms compete with inland provinces in both factor markets and product markets. Although competition can force inland provinces to improve their efficiency and increase productivity, inland provinces are at a competitive disadvantage when facing superior technology, modern management methods, advanced marketing skills and extensive international market networks, high product quality, and high wages and other compensation provided to employees of FDI firms in the coastal regions.

In the factor markets, attracted by greater employment opportunities and the higher wages offered by coastal FDI firms, tens of millions of young and more productive non-skilled workers flow from inland to coastal regions. This is evidenced by the massive flows of migrant workers from inland to coastal regions. Second, attracted by a set of preferential policies, including tax policies, offered to FDI firms, especially in the coastal regions, capital flows from inland provinces to the coastal regions for FDI joint ventures. Third, because of high incomes, high living standards and more carrier development opportunities, skilled labour also flows from inland provinces to coastal regions to work in FDI firms.

In the product markets, because of high quality, famous brand names, advanced domestic and international marketing skills and extensive market networks, as well as good post-sales customer service, coastal FDI firms outperform inland provinces not only in the domestic market by stealing domestic market share from the inland provinces, but also in international export markets by squeezing out inland provinces.

The second point is the lack of industrial linkages between coastal FDI and inland provinces. This may be because coastal FDI firms, on average, are heavily engaged in processing trade, which is based largely on processing imported inputs and exporting final products to world markets. Therefore, backward and 
forward industrial linkages may be absent or very weak between coastal FDI and inland provinces. For example, Fu (2004) uses Chinese province-level data for 1990-99 and finds no evidence of spillovers from coastal export activity into inland regions. She argues that this is because nearly half of export activity in coastal provinces is processing trade that does not provide inter-industry linkages to inland regions. Chen et al. (2013) use Chinese firm-level data from 2000 to 2003 and find that high-exporting FDI firms do not generate technology spillovers to domestic firms because the former are heavily engaged in processing exports and have no backward and forward industrial linkages with domestic firms.

The above analysis has revealed that, on average, coastal FDI has negative impacts on the economic growth of inland provinces because of intense competition in factor and product markets and because of the lack of industrial linkages between coastal FDI firms and inland provinces. However, different coastal provinces attract different types of FDI, especially in the level of engagement in processing trade, which may have different impacts on the economic growth of inland provinces. Therefore, in addition to estimating the average inter-regional spillovers of coastal FDI, it is necessary to estimate the impact of inter-regional spillovers of FDI from different coastal regions on the economic growth of inland provinces.

\section{Estimating the impact on inland provinces of FDI in different coastal regions}

The northern and eastern coastal region and the southern coastal region are the two main destinations for FDI inflows into China. In terms of the level of engagement in processing trade, however, FDI in these two regions is different. Table 14.3 presents the shares of processing trade in the total trade of selected provinces for the period 2003-10. As the table shows, the southern coastal provinces have the highest shares of processing trade, the northern and eastern coastal regions have moderate shares of processing trade and the inland provinces have the lowest shares. On average, FDI firms' trade accounts for more than 50 per cent of China's total trade and is directed heavily towards processing trade, particularly in the southern coastal provinces. Therefore, in terms of trade patterns, FDI in the southern coastal region is mainly engaged in processing trade, FDI in the northern and eastern coastal region is moderately engaged in processing trade and FDI in inland provinces is less engaged in processing trade. 
Table 14.3 Shares of processing trade in selected provinces, 2003-10

\begin{tabular}{|c|c|c|c|c|c|c|c|c|}
\hline & 2003 & 2004 & 2005 & 2006 & 2007 & 2008 & 2009 & 2010 \\
\hline \multicolumn{9}{|c|}{ Coastal provinces } \\
\hline \multicolumn{9}{|l|}{ North and east } \\
\hline Beijing & 23.38 & 23.11 & 24.20 & 22.57 & 24.26 & 34.62 & 39.60 & 34.31 \\
\hline Shanghai & 40.76 & 43.02 & 45.47 & 44.88 & 43.42 & 41.81 & 40.92 & 37.92 \\
\hline Jiangsu & 54.83 & 58.82 & 62.58 & 61.23 & 58.80 & 52.50 & 52.83 & 50.66 \\
\hline \multicolumn{9}{|l|}{ South } \\
\hline Fujian & 42.40 & 44.09 & 43.35 & 41.52 & 38.97 & 38.47 & 33.69 & 34.37 \\
\hline Guangdong & 68.96 & 67.65 & 67.26 & 46.27 & 62.73 & 58.96 & 70.58 & 42.68 \\
\hline \multicolumn{9}{|c|}{ Inland provinces } \\
\hline Shanxi & 2.95 & 5.12 & 9.49 & 12.65 & 23.55 & 15.35 & 11.45 & 13.95 \\
\hline Inner Mongolia & 7.22 & 7.59 & 14.52 & 6.25 & 3.38 & 5.97 & 2.77 & 7.70 \\
\hline Heilongjiang & 4.76 & 5.01 & 4.31 & 3.52 & 3.91 & 4.06 & 6.29 & 3.95 \\
\hline Anhui & 12.62 & 16.41 & 17.92 & 21.99 & 20.14 & 17.76 & 17.18 & 17.65 \\
\hline Jiangxi & 9.23 & 12.93 & 15.41 & 23.26 & 22.69 & 25.59 & 23.61 & 23.35 \\
\hline Henan & 22.87 & 29.83 & 31.49 & 25.82 & 17.67 & 13.01 & 15.02 & 15.71 \\
\hline Hubei & 15.99 & 14.74 & 13.84 & 17.57 & 17.88 & 15.72 & 6.13 & 4.77 \\
\hline Hunan & 7.55 & 10.06 & 8.19 & 10.64 & 11.88 & 5.99 & 10.69 & 17.33 \\
\hline Chongqing & 3.56 & 2.76 & 1.21 & 8.21 & 7.12 & 6.41 & 8.23 & 13.41 \\
\hline Sichuan & 28.15 & 20.91 & 14.33 & 22.40 & 27.83 & 33.54 & 37.23 & 41.83 \\
\hline Shaanxi & 11.06 & 12.84 & 12.37 & 16.74 & 18.54 & 15.48 & 19.00 & 36.02 \\
\hline Gansu & 27.16 & 22.55 & 19.87 & 17.14 & 5.28 & 4.83 & 7.36 & 7.12 \\
\hline Xinjiang & 3.63 & 3.29 & 2.40 & 1.80 & 1.11 & 0.66 & 2.15 & 1.53 \\
\hline
\end{tabular}

Sources: Calculated from Qiu (2013); and NBS (various issues).

Knowledge spillovers through backward and forward industrial linkages are among the most important channels through which technology, management skills and marketing information are transferred from FDI firms to the local economy. Therefore, we can hypothesise that FDI in coastal regions engaged in different trade activities - processing and ordinary trade - could have different impacts on inland provinces. FDI firms engaged mainly in processing trade would have no impact on inland provinces because of the lack of industrial linkages or a negative impact by reducing demand for intermediate inputs from and competing in world export markets with inland provinces. FDI firms engaged mainly in ordinary trade would generate positive knowledge spillovers to inland provinces through industrial linkages by sourcing raw materials and intermediate inputs from inland provinces. 
We also use Equation 14.3 to conduct the regression; however, the variable of coastal region FDI stock $(C R F K)$ is replaced with two variables: the northern and eastern coastal region FDI stock (N\&ECRFK) and the southern coastal region FDI stock (SCRFK). The estimation results (see Table 14.4) show that FDI in the northern and eastern coastal region $(N \& E C R F K)$ generates positive and statistically significant (at the 5 per cent level) spillovers on the economic growth of inland provinces, while FDI in the southern coastal region (SCRFK) has a negative and statistically significant (at the 1 per cent level) impact on the economic growth of inland provinces.

Table 14.4 Estimating inter-regional spillovers from coastal FDI in different trade activities on inland province economic growth, 1987-2010 (dependent variable: $\operatorname{Ln} Y$ )

\begin{tabular}{|l|r|}
\hline Independent variables & Fixed effects \\
\hline Constant & 1.8028 \\
\hline LnL & $(10.08)^{* * *}$ \\
\hline LnDK & -0.0865 \\
& $(-1.65)^{*}$ \\
\hline LnFK & 0.3969 \\
& $(15.99)^{* * *}$ \\
\hline HK & 0.0530 \\
& $(8.45)^{* * *}$ \\
\hline$t$ & 0.0035 \\
& $(0.21)$ \\
\hline SFKt-1 & 0.0496 \\
& $(13.99)^{* * *}$ \\
\hline LnN\&ECRFKt-1 & 0.0052 \\
& $(1.15)$ \\
\hline LnSCRFKt-1 & 0.1053 \\
\hline LnOIRFKt-1 & $(2.43)^{* *}$ \\
\hline No. of observations & -0.3066 \\
No. of groups & $(-8.44)^{* * *}$ \\
R & 0.1334 \\
F-statistics & $(5.16)^{* * *}$ \\
\hline
\end{tabular}

* Statistically significant at 0.10 level.

** Statistically significant at 0.05 level.

*** Statistically significant at 0.01 level.

Note: t-statistics are in parentheses.

Source: Author's own estimations. 
Why does FDI in the southern coastal region have a negative spillover on inland provinces while FDI in the northern and eastern region generates positive spillovers on inland provinces? Because FDI in the southern coastal region is heavily engaged in processing trade, it not only reduces demand for intermediate inputs from firms in inland provinces, due to a lack of backward and forward industrial linkages, it also competes in world export markets with inland firms, generating a negative impact on their economic growth. FDI in the northern and eastern coastal region is moderately engaged in processing trade, and although it also competes with firms in inland provinces, it does have a certain level of backward and forward industrial linkages with inland provinces through sourcing raw materials and intermediate inputs from inland firms and selling intermediate inputs to those firms, thus generating some positive spillovers on inland provinces. Therefore, the empirical estimation results support our hypothesis that FDI in coastal regions engaged in different trade patterns - processing versus ordinary trade - has different impacts on the economic growth of inland provinces.

It is also interesting to note that the variable of OIRFK-FDI stock in other inland provinces - is consistently positive and significant in all regressions, implying that FDI in other inland provinces generates positive spillovers on the economic growth of inland provinces. As discussed above, FDI in inland provinces is less engaged in processing trade and more engaged in ordinary trade. Therefore, FDI in inland provinces has extensive backward and forward industrial linkages with firms in other inland provinces, which enhance the transfer of knowledge spillovers from FDI to local economies, thus contributing to the economic growth of inland provinces. This finding provides further evidence of the importance of industrial linkages in enhancing knowledge spillovers from FDI to the local economy.

\section{Conclusion}

The main purpose of this study is to investigate empirically the impact of interregional spillovers from coastal FDI on the economic growth of China's inland provinces, with a particular emphasis on how this impact is affected by the level of engagement of FDI in processing trade in different coastal regions. The study finds that, on average, coastal FDI has a negative impact on the economic growth of inland provinces. However, by dividing coastal FDI into a northern and eastern region and a southern region, the study finds that FDI in southern coastal provinces still has a negative impact on the economic growth of inland provinces because of intense competition in both factor markets and product markets, and because of a lack of backward and forward industrial linkages with inland provinces because of heavy engagement in processing trade. FDI 
in the northern and eastern coastal provinces, however, has positive spillovers through backward and forward industrial linkages with inland provinces because of moderate engagement in processing trade and a certain level of local sourcing. FDI in other inland provinces has positive spillovers on the economic growth of inland provinces through backward and forward industrial linkages due to the low level of engagement in processing trade and a high level of local sourcing. Therefore, this study provides further evidence of the importance of industrial linkages in enhancing knowledge spillovers from FDI to the local economy. The study also finds that spillovers from inland province FDI are absent because of the low level of FDI inflows into those provinces.

The findings of this study imply that China's inland provinces still have a lot of benefits to gain from the inflow of FDI. First, China should design policies to help inland provinces improve local economic and technological conditions and their overall investment environment in order to attract more FDI inflows. The implementation of the 'Western Development Strategy' and the 'One Belt and One Road Development Strategy' will greatly improve the investment environment of inland provinces. Second, China should redesign processing trade policies to focus on increasing local sourcing and enhancing industrial linkages through economic structural reform and industrial upgrading. Third, China should encourage contact, information exchange, production and technological cooperation, and joint R\&D activities between FDI firms and domestic firms in general and between coastal FDI firms and inland firms in particular, in order to enhance and accelerate the diffusion of positive knowledge spillovers from FDI to China's economy.

\section{References}

Aitken, B. and Harrison A. (1999), Do domestic firms benefit from direct foreign investment? Evidence from Venezuela, American Economic Review, 89(3): 605-18.

Bao, S., Bodvarsson, O., Hou, J. and Zhao, Y. (2007), Interprovincial migration in China: The effects of investment and migrant networks, IZA Discussion Paper No. 2924, Bonn: Institute for the Study of Labor.

Branstetter, L. and Feenstra, R. (2002), Trade and foreign direct investment in China: A political economy approach, Journal of International Economics, 58(2): 335-58.

Bronzini, R. and Piselli, P. (2009), Determinants of long-run regional productivity with geographic spillovers: The role of R\&D, human capital and public infrastructure, Regional Science and Urban Economics, 39(2): 187-99. 
Brun, J., Combes, J. and Renard, M. (2002), Are there spillover effects between coastal and noncoastal regions in China?, China Economic Review, 13(2-3): $161-9$.

Cai, F. and Wang, D. (2003), Migration as marketisation: What can we learn from China's 2000 census data?, China Review, 3(2): 73-93.

Caves, R. (1996), Multinational Enterprise and Economic Analysis, 2nd edn, Cambridge: Cambridge University Press.

Chen, C. (2011), Foreign Direct Investment in China: Location determinants, investor differences and economic impacts, Cheltenham, UK, and Northampton, Mass.: Edward Elgar.

Chen, C. (2013), FDI and economic growth, in Wu, Y. (ed.), Regional Development and Economic Growth in China, Series on Economic Development and Growth No. 7, Singapore: World Scientific, pp. 117-40.

Chen, C. (2014), The impact of FDI on China's regional economic growth, in Song, L., Garnaut, R. and Cai, F. (eds), Deepening Reform for China's LongTerm Growth and Development, Canberra: ANU Press, pp. 407-27.

Chen, C., Sheng, Y. and Findlay, C. (2013), Export spillovers of FDI on domestic firms, Review of International Economics, 21(5): 841-56.

Du, Y., Park, A. and Wang, S. (2005), Migration and rural poverty in China, Journal of Comparative Economics, 33(4): 688-709.

Dunning, J. (1993), Multinational Enterprises and the Global Economy, Wokingham, UK: Addison-Wesley.

Fosfuri, A., Motta, M. and Ronde, T. (2001), Foreign direct investment and spillovers through workers' mobility, Journal of International Economics, 53(1): 205-22.

$\mathrm{Fu}, \mathrm{X} .(2004)$, Limited linkages from growth engines and regional disparities in China, Journal of Comparative Economics, 32(1): 148-64.

Fu, X. (2011), Processing trade, FDI and the exports of indigenous firms: Firmlevel evidence from technology-intensive industries in China, Oxford Bulletin of Economics and Statistics, 73(6): 792-817.

Funke, M. and Niebuhr, A. (2005), Regional geographic research and development spillovers and economic growth: Evidence from West Germany, Regional Studies, 39(1): 143-53. 
Girma, S. and Gong, Y. (2008), FDI, linkages and the efficiency of state-owned enterprises in China, Journal of Development Studies, 44(5): 728-49.

Girma, S. and Wakelin, K. (2007), Local productivity spillovers from foreign direct investment in the UK electronics industry, Regional Science and Urban Economics, 37(3): 399-412.

Girma, S., Gorg, H. and Pisu, M. (2004), The role of exporting and linkages for productivity spillovers, GEP Research Paper No. 2004/30, Nottingham: Nottingham Centre for Research on Globalisation and Economic Policy.

Halpern, L. and Murakozy, B. (2007), Does distance matter in spillover?, Economics of Transition, 15(4): 781-805.

Holger, G. and Strobl, E. (2005), Spillovers from foreign firms through worker mobility: An empirical investigation, The Scandinavian Journal of Economics, 107(4): 693-709.

Hu, A. and Jefferson, G. (2002), FDI impact and spillover: Evidence from China's electronic and textile industries, World Economy, 38(4): 1063-76.

Hu, A., Jefferson, G. and Qian, J. (2005), R\&D and technology transfer: Firmlevel evidence from Chinese industry, The Review of Economics and Statistics, 87(4): 780-6.

Javorcik, B. (2004), Does foreign direct investment increase the productivity of domestic firms? In search of spillovers through backward linkages, The American Economic Review, 94(3): 605-27.

Keller, W. (2002), Geographic localization of international technology diffusion, American Economic Review, 92(1): 120-42.

Kneller, R. and Pisu, M. (2007), Industrial linkages and export spillovers from FDI, The World Economy, 30(1): 105-34.

Kugler, M. (2006), Spillover from foreign direct investment: Within or between industries, Journal of Development Economics, 88(2): 444-77.

Kuo, C. and Yang, C. (2008), Knowledge capital and spillover on regional economic growth: Evidence from China, China Economic Review, 19(40): 594-604.

Liu, X., Wang, C. and Wei, Y. (2009), Do local manufacturing firms benefit from transactional linkages with multinational enterprises in China?, Journal of International Business Studies, 40(7): 1113-30.

Liu, Z. (2008), Foreign direct investment and technology spillovers: Theory and evidence, Journal of Development Economics, 85(1-2): 176-93. 
Madariaga, N. and Poncet, S. (2007), FDI in Chinese cities: Spillovers and impact on growth, World Economy, 30(5): 837-62.

National Bureau of Statistics of China (NBS) (various issues), China Statistical Yearbook, Beijing: China Statistics Press.

Nunnenkamp, P. and Stracke, R. (2007), Foreign direct investment in post-reform India: Likely to work wonders for regional development?, Working Paper No. 1375, Kiel: Kiel Institute of World Economics.

Ouyang, P. and Fu, S. (2012), Economic growth, industrial development and the inter-regional spillovers from foreign direct investment: Evidence of China, China Economic Review, 23(2): 445-60.

Provincial Bureau of Statistics (PBS) (various issues for each province), Provincial National Economic and Social Development Statistical Bulletin, Beijing: China Statistics Press.

Qiu, W. (2013), Situation of China's processing trade and strategies, Paper, Available at paper.people.com.cn/rmlt/html/2013-08/11/content_1295002.htm. Accessed 30 January 2015.

Rozelle, S., Taylor, E. and Brauw, A. (1999), Migration, remittances, and agricultural productivity in China, American Economic Review, 89(2): 287-91.

Wang, L., Meijers, H. and Szirmai, A. (2013), Technological spillovers and industrial growth in Chinese regions, UNU-MERIT Working Paper Series No. 2013-044, Tokyo: United Nations University.

$\mathrm{Wu}, \mathrm{Y}$. (2009), China's capital stock series by region and sector, Discussion Paper No. 09.02, Perth: Business School, University of Western Australia, Available at www.business.uwa.edu.au/_data/assets/pdf_file/0009/260487/09_02_ Wu.pdf. Accessed 30 January 2015.

$\mathrm{Xu}, \mathrm{X}$. and Sheng, Y. (2012), Are FDI spillovers regional? Firm-level evidence from China, Journal of Asian Economics, 23(3): 244-58.

Zhang, Q. and Felmingham, B. (2002), The role of FDI, exports and spillover effects in the regional development of China, Journal of Development Studies, 38(4): 157-78. 
This text is taken from China's Domestic Transformation in a Global Context, edited by Ligang Song, Ross Garnaut, Cai Fang \& Lauren Johnston, published 2015 by ANU Press, The Australian National University, Canberra, Australia. 